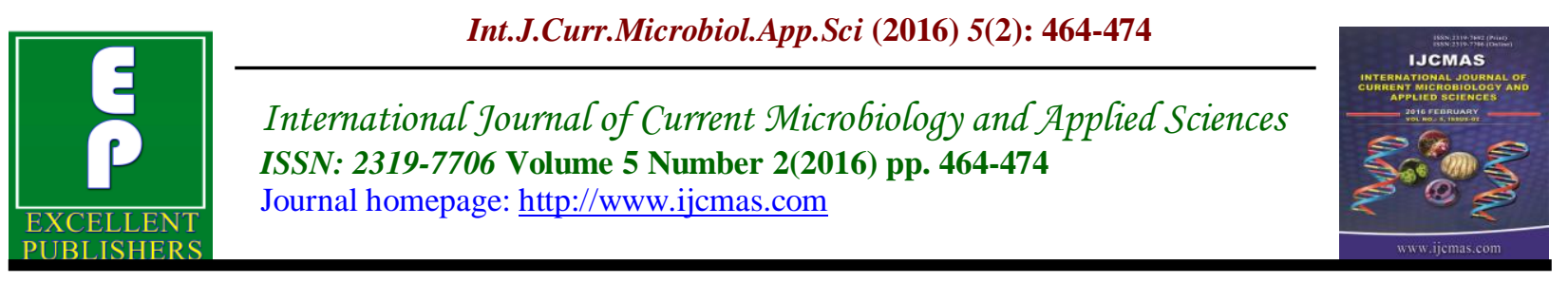

Original Research Article

doi: http://dx.doi.org/10.20546/ijcmas.2016.502.052

\title{
A study of Bioremediation of Methyl Parathion in vitro using Potential Pseudomonas sp. isolated from Agricultural Soil, Visakhapatnam, India
}

\author{
S.Sharmila Begum ${ }^{1} *$ and A.Arundhati ${ }^{2}$ \\ ${ }^{1}$ Department of Biotechnology, Dr. L.Bullayya PG.College, \\ Visakhapatnam, Andhra Pradesh, India \\ ${ }^{2}$ Department of Botany, Andhra University, Visakhapatnam, Andhra Pradesh, India \\ *Corresponding author
}

\begin{abstract}
A B S T R A C T
Keywords

P. aeruginosa,

Methyl

Parathion,

Pesticide,

Biodetoxification

Article Info

Accepted:

23 January 2016

Available Online:

10, February 2016

The present investigation deals with screening and isolation of Methyl parathion (MP) degrading bacteria from local agriculture soil and study of its biodetoxification efficiency in vitro using potential Pseudomonas sp R2. The potent isolates that could degrade Methyl Parathion were identified as Pseudomonas species $R 1, R 2$ and $R 3$ respectively. Effect of $\mathrm{pH}$ and temperature on growth profile of these isolate revealed $30^{\circ} \mathrm{C}$ as the optimum temperature at $500 \mu \mathrm{g} / \mathrm{ml}$. But, the growth was optimized at $\mathrm{pH} 7$ and $37^{\circ} \mathrm{C}$ to be used for an added advantage in cloning the Methyl Parathion degrading (mpd) in E. coli. The three Pseudomonas isolates were found to tolerate a concentration of $3800 \mu \mathrm{g} / \mathrm{ml}$ and $\mathrm{R} 2$ isolate identified as Pseudomonas aeruginosa species which is capable of degrading $1920 \mu \mathrm{g} / \mathrm{ml} \mathrm{MP}$ after $48 \mathrm{hrs}$ in in vitro studies.
\end{abstract}

\section{Introduction}

India is primarily an agriculture based country along with a well established agrochemical industry. The demand of organophosphate (OPs) is on rise in accordance to an alarming population rise in India, projected to cross 1.3 billion by 2020 (Kanekar et al., 2004). Currently OPs account for about one-third the total pesticide consumption (Zamy et al., 2004) with agro-based industries and farmers relying on low cost, broad spectrum organophosphate pesticides (OPs) to protect and improve crop production. The global scenario of OPs is in no way different. Organophosphate pesticides such as Parathion and Methyl Parathion (MP) come handy and used extensively as agriculture and domestic pesticides. It is a contact and ingestion insecticide, having $\mathrm{P}=\mathrm{S}$ bond and due to its low persistence in the environment its utility is indispensable in agriculture. In discriminate use of these pesticides has lead to contamination of soil and ground 
water (Ahmed et al., 2008). Owing to its xenobiotic nature, its disposal in biosphere poses tremendous problem and its presence is a serious threat to environment and indeed to human life (Hashmi et al., 2009 and Ritmann et al., 1988). Besides combating insect pests, it also affect the population and activity of beneficial microbial communities in soil (Pandey and Singh, 2004). Several reports of frequent occurrence of health hazards to human being and many biotic species exposed to it, has raised a serious concern. Due to inhibition of acetylcholine esterase activity, its effect is disastrous as shown by the LD50 value. It is as low as 14 to $24 \mathrm{mg} / \mathrm{kg}$ of body weight (Amna salman et al., 2010). Frequent reports of muscular and nerve ending related cases have came to light. There is no clear-cut system to ensure that pesticides are managed in a sound manner. Although, commendable efforts have been undertaken to regulate pesticide use in the country by Environmental Protection Agency (EPA) and Central Insecticides Board and Registration Committee (CIBRC) there is no proper disposal system. The ultimate strategy adopted is banning and restriction. Consequently, such pesticides (OPs) are dumped into open wastelands and water resources. The contamination issue therefore is evolving on a larger scale with higher doses . Although physical and chemical detoxification methods along with natural processes of volatilization, degradation (microbiological and abiotic) and leaching are available to remove residual pesticides; the environmental hazards of these methods are drastically many. From various reports available (Theriot CM and Gruden 2011), a large number of microbial enzymes are known to have the ability to degrade harmful organophosphorous compounds that are present in some pesticides and nerve agents. Thus, biodetoxification of the xenobiotic compounds can be carried out by use of biological agent i.e., microbes (Sharmila et al., 1989). Microorganisms have been reported to mediate in both soilbound pesticide formation and pesticide degradation (Gevao et al., 2000). For dissociating pesticides, sorption properties of the molecule can be modified by a $\mathrm{pH}$ adjustment (Ou LT et al 1983,Spadotto and Hornsby, 2003). The use of biological agents to overcpome the deleterious effects by removal of xenobiotic compound is termed as "bioremediation". Based on this background information, the present work has been designed to isolate an efficient soil bacterium strain capable of degrading Methyl parathion from indigenous soil sample. Further, the degradation capacity enhancement is tried by enrichment, optimization and subculturing studies. We look here for a novel strain with highest tolerance to pesticide and simultaneous degradation of MP in vitro at higher doses of contamination.

\section{Materials and Methods}

\section{Pesticide}

Commercial grade Methyl parathion Agro chemical was procured from local pesticides shop. A standard stock of $10 \mathrm{mg} /$ $\mathrm{ml}$ was prepared in laboratory and a series of working standards with different concentration ranging from $500 \mu \mathrm{g} / \mathrm{ml}$ to $4000 \mu \mathrm{g} / \mathrm{ml}$ was formulated according to experiment design.

\section{Media Preparation}

Nutrient Agar Medium (NAM) contained the following ingredients (in grams per liter): Peptone, 5.0; Beef Extract, 3.0; NaCl, 5.0; Agar, 15.0 was prepared. The $\mathrm{pH}$ value was maintained to $7.0 \pm 0.2$ and then the medium was sterilized by autoclaving at $121^{\circ} \mathrm{C}, 15$ psi pressure for 15 minutes. 
NAM containing $500 \mu \mathrm{g} / \mathrm{ml}$ concentration of Methyl parathione was used for isolation of Methyl parathione degrading bacteria. Mineral Salt medium MSM with no-carbon no-energy source medium was prepared by mixing $4.8 \mathrm{~g}$ K2HPO4, $1.2 \mathrm{~g} \mathrm{KH} 2 \mathrm{PO} 4,1.0$ g NH4NO3, $0.25 \mathrm{~g}$ MgSO4.7H2O, $0.04 \mathrm{~g}$ $\mathrm{CaCl} 2$ and $0.005 \mathrm{~g} \mathrm{FeSO} 4.7 \mathrm{H} 2 \mathrm{O}$ in one liter of distilled water. The medium was autoclaved. Medium without MP served as control in the experiment. MSM containing various concentration of MP was used for maintenance of culture and study of degradation of MP in culture.

\section{Sample Collection}

Soil sample were collected using random sampling method, from agricultural fields in and around Visakhapatnam, Andhra Pradesh, India. Commercial crops like paddy, and chilly were extensively grown and methyl parathion were used intensively in these fields. Sample was collected in polythene bags, air dried and filtered through a mesh to collect only the granular content and other plant material waste was manually removed. The processed sample was stored in cold $\left(4^{\circ} \mathrm{C}\right)$ sterile condition till processed.

\section{Screening of Methyl Parathion Degrading Bacteria}

Bacteria capable of degrading Methyl Parathion was screened from soil using enrichment technique. By incorporating Methyl Parathion in the soil, microbes were enriched. $10 \mathrm{~g}$ of the soil sample was mixed with $500 \mu \mathrm{g} / \mathrm{ml}$ of standard MP and $50 \mathrm{ml}$ of distilled water. The supernatant was suspended in $50 \mathrm{ml} \mathrm{MSM} \mathrm{in} \mathrm{a} 250 \mathrm{ml}$ Erlenmeyer flasks. Flasks were incubated on a shaker operating at $120 \mathrm{rpm}$ for $72 \mathrm{hrs}$ at ambient temperature $\left(30{ }^{\circ} \mathrm{C} \pm 2{ }^{\circ} \mathrm{C}\right)$. The growth was monitored initially for a period of 7 days by turbidometric method. With increase in turbidity, concentration of MP was gradually increased at one week interval. The maximum concentration subjected during enrichment was up to $2500 \mu \mathrm{g} / \mathrm{ml}$. After three cycles of experiments in three months, the enriched soil sample was subjected to serial dilution technique. $1 \mathrm{ml}$ of the sample was withdrawn from the flasks containing different concentrations of Methyl Parathion and subjected to serial dilution up to $10-9$ dilution. $100 \mu \mathrm{l}$ of the sample from the highest concentration was used for surface spreading on Nutrient Agar medium supplemented with Methyl Parathion. The viable colonies obtained after incubation at $37^{\circ} \mathrm{C}$ for $24-48$ hours were counted using colony counter. The growth of individual colonies was expressed in terms of $\mathrm{cfu} / \mathrm{ml}$. After three consecutive transfers, mixed bacterial cultures were collected on BMM agar plates containing $50 \mathrm{mg} / \mathrm{L} \mathrm{MP}$ and tested for MP degrading ability, and pure culture were isolated.

\section{Isolation and Purification of Bacterial Colonies}

After enrichment process, pure cultures of isolated bacteria used in the present investigation were cultured on enriched nutrient agar medium containing $500 \mu \mathrm{g} / \mathrm{ml}$ of MP and streaked on MSM with 500 $\mu \mathrm{g} / \mathrm{ml}$ MP of and stored at $4^{\circ} \mathrm{C}$ in refrigerator. The culture was maintained by regular subculturing at 15 days interval.

\section{Preparation of Inoculums}

Single isolates were streaked separately on Nutrient Agar plates and a single colony obtained after overnight incubation at $37^{\circ} \mathrm{C}$ was inoculated in $5 \mathrm{ml}$ Nutrient broth in 150 $\mathrm{ml}$ flask. After growth, $1.5 \mathrm{ml}$ of overnight culture incubated at $120 \mathrm{rpm}, 37^{\circ} \mathrm{C}$ was 
transferred into eppendorf and centrifuged at $5000 \mathrm{rpm}$ for $5 \mathrm{~min}$. The pellets were washed twice with sterile normal saline $(0.85 \%)$ at $4{ }^{\circ} \mathrm{C}$, on $12000 \mathrm{rpm}$ for 5 minutes. The cells were re-suspended in sterile $95 \mathrm{ml}$ of MSM (V/V), containing $500 \mu \mathrm{g} / \mathrm{ml}$ of MP and incubated at $37^{\circ} \mathrm{C}$ at $120 \mathrm{rpm}$, maintaining $\mathrm{pH}$ at 7 . The prepared inoculum was used for subsequent experiment.

\section{Effect of Time on the Growth of Methyl Parathion Degrading Bacteria}

The inoculum in the log phase, was inoculated in fresh MSM (V/V), containing $500 \mu \mathrm{g} / \mathrm{ml} \mathrm{MP}$ and incubated at $37^{\circ} \mathrm{C}$ and $120 \mathrm{rpm}$, at $\mathrm{pH}$ 7. Media without inoculum served as controls. The same procedure was applied for each isolate. Microbial growth at $0,2,4,6,24,36,48,72$ and $120 \mathrm{hrs}$ of inoculation was measured spectrophotometrically at $600 \mathrm{~nm}$.

\section{Screening and Selection of Potential Methyl Parathion Degrading Bacteria}

Solid agar media MSM containing 500 $\mu \mathrm{g} / \mathrm{ml}$ to $4000 \mu \mathrm{g} / \mathrm{ml}$ MP was prepared. $100 \mu 1$ of the prepared inoculums was used for surface spreading. Similarly, $5 \mathrm{ml}$ culture was inoculated in $95 \mathrm{ml}$ liquid MSM culture media. Single colonies from the highest concentration were used for further purification and testing of their growth tolerance. The protocol for growth and measurement is as previously described

\section{Determination of Methyl Parathion Dose Tolerated and Utilized by Isolates}

In order to investigate, the maximum limits of MP tolerated and utilized by bacterial isolates as sole carbon and energy source, 5 $\mathrm{ml}$ of the inoculum of each isolates were inoculated separately in fresh $95 \mathrm{ml}$ MSM (V/V), containing $500 \mu \mathrm{g} / \mathrm{ml}-4000 \mu \mathrm{g} / \mathrm{ml}$
MP. Control was prepared separately for each sample which was devoid of MP. Flasks were incubated at $37^{\circ} \mathrm{C}$ and $120 \mathrm{rpm}$, at $\mathrm{pH}$ 7. The growth was monitored by spectrophotometer at $600 \mathrm{~nm}$ after $48 \mathrm{hrs}$, as described in the above method.

\section{Quantification of Methyl Parathion Concentration by GC}

Degradation of MP was analysed by gas chromatography (GC). Isolates were taken which showed maximum growth at high MP concentration. Parallel controls (without culture) were also run and taken for comparison purposes. Tubes were centrifuged at $12000 \mathrm{rpm}$ for $15 \mathrm{~min}$ at $4^{\circ} \mathrm{C}$, supernatant was collected in tube and extracted with dichloromethane. Dichloromethane extracts were analysed by GC (Varian CP 3800 model).

\section{Identification of Potential Methyl Parathion Degrading Isolates}

Bacterial isolates that could grow at relatively high concentration of pesticide MP were subjected to morphological, cultural and biochemical tests. The isolated organisms were characterized morphologically by gram's staining and biochemical characterization which included tests like: Carbohydrate fermentation test, Oxidase test, Catalase test, Coagulase test, Hugh and leifson's oxidation fermentation test etc. The procedure of Bergey's Manual of Systematic Bacteriology was followed for identification of the strains.

\section{Results and Discussion}

\section{Isolation of MP Degrading Bacteria}

Methyl Parathion degrading 14 bacterial species were isolated from agricultural soil, in and around Visakhapatnam, where 
commercial crops like paddy and chilly were extensively grown and the pesticide was used intensively. By contemplating such soil would contain natural micro-flora experiencing pesticide stress. These species were isolated by enrichment method in MSM containing MP.

The original color of commercial MP disappeared within $12 \mathrm{hrs}$ and turbidity developed in medium from $12 \mathrm{hrs}$ to 48 hours. The color of the medium was changed from faint lemon color to white. 14 isolates were screened initially which were capable for growing in MSM with 500 $\mu \mathrm{g} / \mathrm{ml}$ MP (Graph1). These isolates were purified in Nurient agar plates containing $500 \mu \mathrm{g} / \mathrm{ml} \mathrm{MP}$. The isolated bacteria were labeled as SSB series.

\section{Isolates Utilize Methyl Parathion as a Source of Carbon and Energy}

Bacteria utilized MP as a carbon and energy source was confirmed by this experiment. The growth was observed after $48 \mathrm{hrs}$ of incubation in MSM formulated media containing $500 \mu \mathrm{g} / \mathrm{ml}-4000 \mu \mathrm{g} / \mathrm{ml} \mathrm{MP}$. But this growth was not recorded in the control which was devoid of MP (Graph 2).

\section{Effect of Time on Growth of Methyl Parathion Degrading Bacteria}

The maximum growth was recorded after 48 hrs of incubation (Graph 1) in all the fourteen bacterial isolates screened (nutrient agar-solid medium) from enriched sample in MSM containing $500 \mu \mathrm{g} / \mathrm{ml} \mathrm{MP}$ (liquid). The best three isolates with confluent growth in solid and liquid media were marked as isolates $\mathrm{R} 1, \mathrm{R} 2$ and $\mathrm{R} 3$ respectively. This growth was confirmed by optical density at 600nm (Graph 4). No growth was observed in uninoculated control (-ve) and a slight turbidity was there in inoculated control (+ve).

\section{Selection of Potential Methyl Parathion Degrading Bacteria}

Three bacterial isolates- Isolate R1, Isolate $\mathrm{R} 2$ and Isolate R3 were selected on the basis of their growth at $2500 \mu \mathrm{g} / \mathrm{ml}$. The maximum growth was observed after $48 \mathrm{hrs}$ of incubation (Graph 4). The three Pseudomonas isolates were found to tolerate a concentration of $3800 \mu \mathrm{g} / \mathrm{ml}$ and one of the isolate has shown to degrade $1920 \mu \mathrm{g} / \mathrm{ml} \mathrm{MP}$ after 48 hrs. Such a high MP degrading potential by an isolate has not been reported so far (Graph 5).

Soil environment is characterized by the presence of multiple xenobiotic organic substances, incorporated deliberately due to modern agricultural practices (Gupta PK, 2004). In many reports micro organism have been known to mediate in a defensive way to detoxify the site, by soil-bound pesticide formation and pesticide degradation (Gevao et al., 2000). It is a proven fact that Methyl Parathion have an effect on soil bacterial activity (Bindhya, et $a l ., 2009)$ and biodegradation of Methyl parathion is possible by newly isolated bacteria species like Bacillus pumilus (Ali, M., K.N. Ahmed et al., 2011).

The number of microbes in mixed culture showed a decline in the optical density with increased concentration of methyl parathion implies that presence of insecticide effects the soil microflora in field as well as in vitro (Ahmed and Ahmed, 2006). The study indicates that few microbes were capable of growing at $500 \mu \mathrm{g} / \mathrm{ml}$ concentration and utilizes MP as a source of carbon and energy. Subsequent investigation with the best three isolates, revealed their tolerating capacity increases up to a concentration of $2500 \mu \mathrm{g} / \mathrm{ml} \mathrm{MP}$. The investigated isolates survived after $48 \mathrm{hrs}$ with substantial amount of degradation rate at this concentration. 


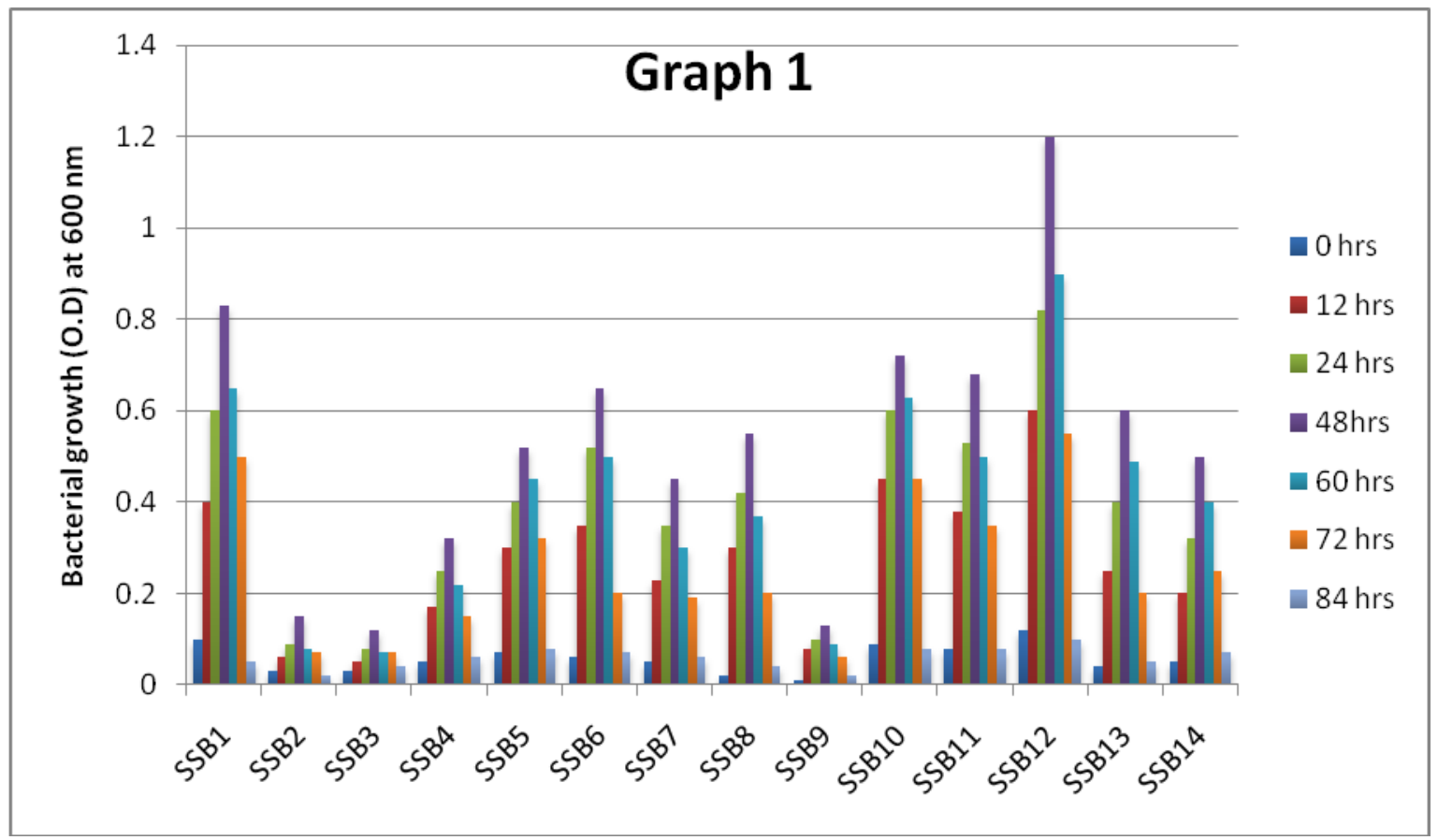

Graph.1 Growth profile of pesticide degrading bacterial isolates in MSM $+500 \mu \mathrm{g} / \mathrm{ml} \mathrm{MP}$, at different time interval ( $0 \mathrm{hrs}$ to $84 \mathrm{hrs}$ ), at $30^{\circ} \mathrm{C}, 120 \mathrm{rpm}, \mathrm{pH} 7$.

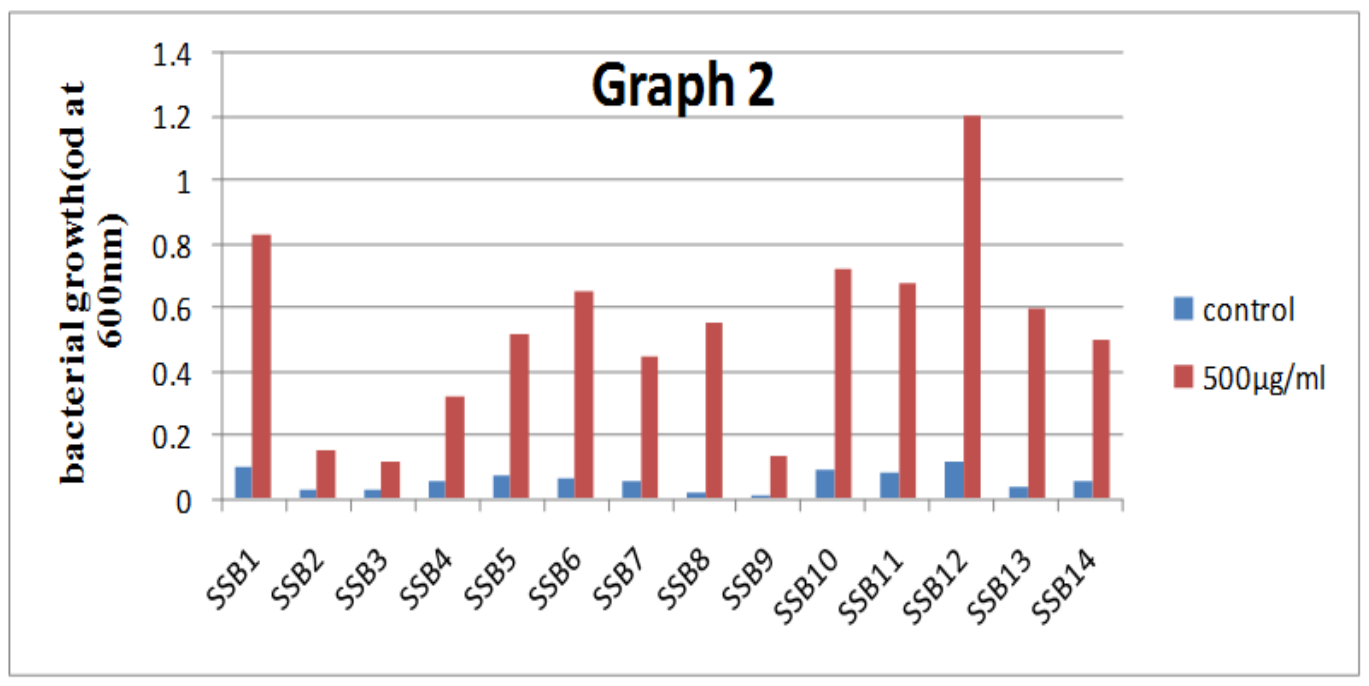


Graph.2 Growth of isolates in MSM in the control and enriched media with $500 \mu \mathrm{g} / \mathrm{ml} \mathrm{MP}$ at $37^{\circ} \mathrm{C}$, pH 7, and $120 \mathrm{rpm}$ after $48 \mathrm{hrs}$.

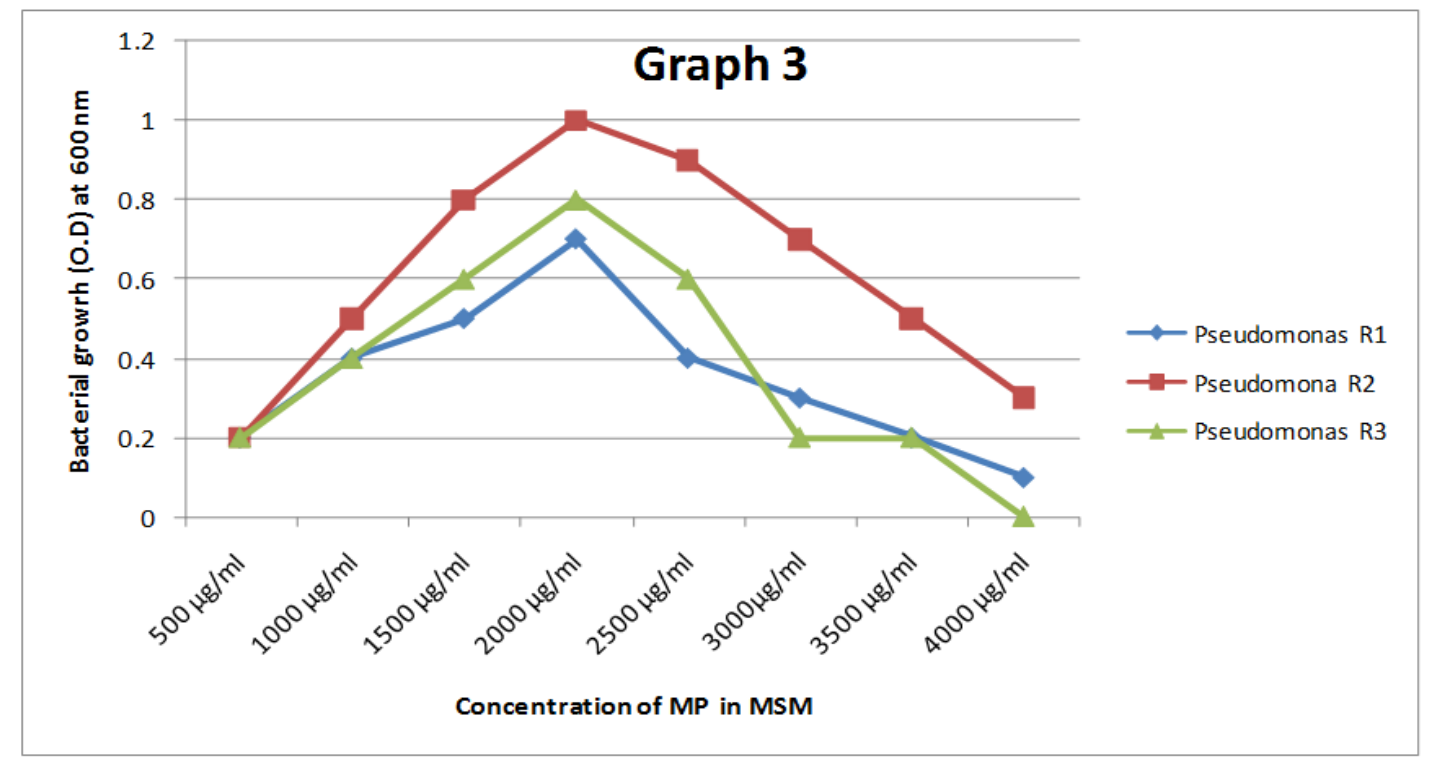

Graph.3 Growth of Potential isolate at different concentration of MP $(500 \mu \mathrm{g} / \mathrm{ml}$ to $4000 \mu \mathrm{g} / \mathrm{ml})$
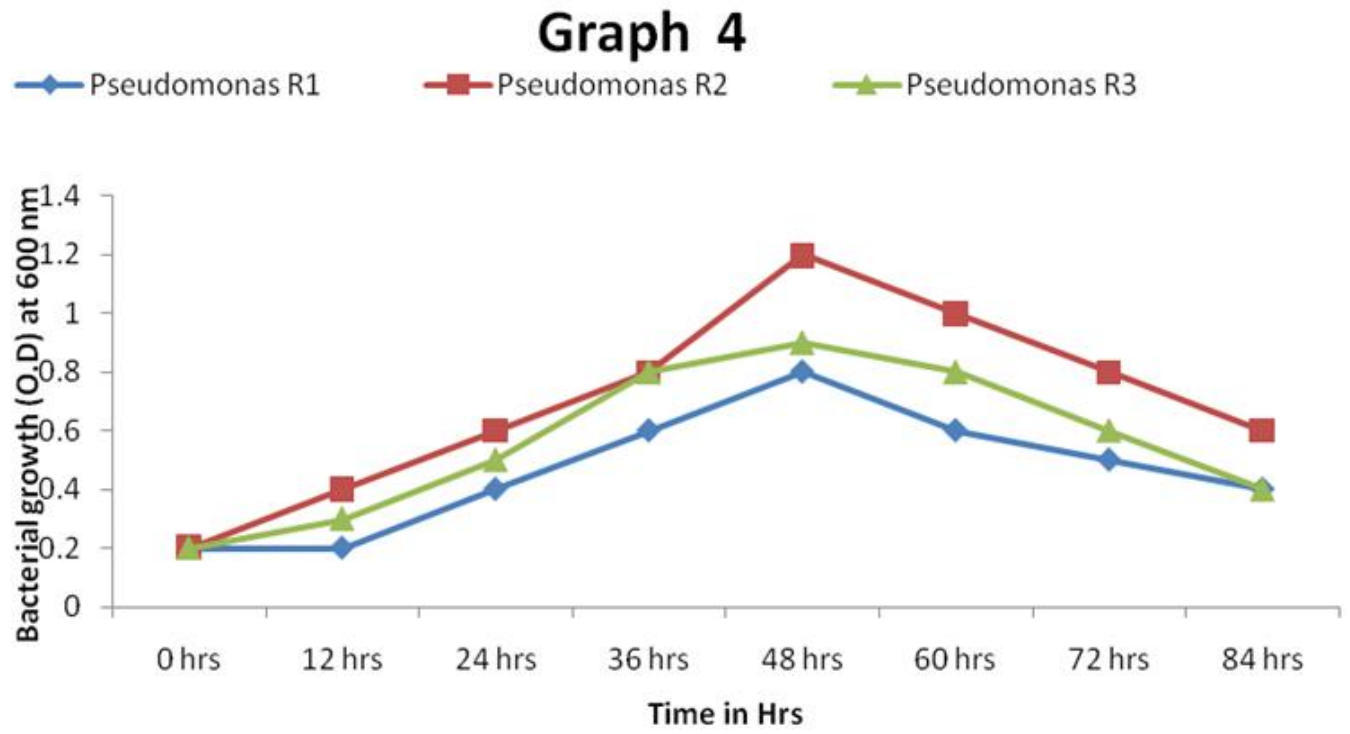
Graph.4 Effect of different time intervals on growth curve of potential MP degrading isolates in $\mathrm{BMM}$ at $500 \mu \mathrm{g} / \mathrm{ml}$ at $37^{\circ} \mathrm{C}, \mathrm{pH} 7$

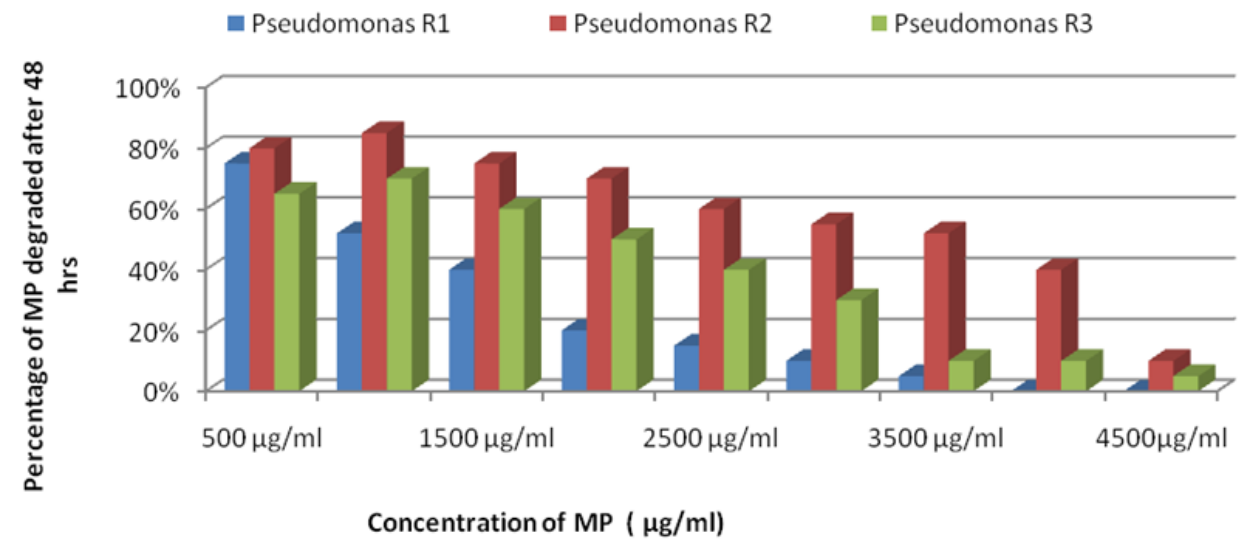

Graph.5 Percentage of degradation of different concentration of MP by three potential isolates

Table.1 Biochemical Characteristic of Methyl parathion degrading isolates, isolated from thesoil sample

\begin{tabular}{llcc}
\hline Test & Isolate 1 & Isolate 2 & Isolate3 \\
Gram's reaction & - & - & - \\
Cell shape & Rod shaped & Rod shaped & Rod shaped \\
Motility & + & + & + \\
Catalase & + & + & + \\
Oxidase & + & + & + \\
Methyl-red & - & - & - \\
Voges-Proskauer test & - & - & - \\
H2S production & - & - & - \\
Indole test & - & - & - \\
Citrate test & + & + & - \\
Hydrolysis of starch & - & - & + \\
Urease test & - & + & - \\
Casein hydrolysis test & + & + & \\
Gelatin liquefaction & + & & \\
\end{tabular}

Isolate1: Pseudomonas sp.R1

Isolate2: Pseudomonas sp.R2

Isolate3: Pseudomonas sp.R3

The isolates were identified as Pseudomonas species $R 1, R 2$ and $R 3$ respectively. Pseudomonas sp. $R 2$ was found to be a promising strain with high resistance and degradation capacity. Several investigators have isolated different bacterial species from Organophosphorus MP pre-treated agricultural soil by these method in aqueous medium (Charoensri, $\mathrm{K}$ et al., and Keprasertsup et al.,2001) and solid medium. 
Further, growth and maintenance of these isolates on nutrient agar, shows a confluent growth in accordance with studies showing biodegradation of organophosphorus pesticides in the presence of additional energy sources in, nutrient broth. These species were capable of degrading the commercial grade MP used in this study, implying the compound used in preparation of this formulation might promote the growth of these bacteria in combination with components of MSM media. Similar studies by Ou, L.T and A. Sharma, 1989, reveals the degradation of methyl parathion by mixed bacterial culture and a Bacillus sp. isolated from different soils. In the present study three Pseudomonas isolates were found to tolerate a concentration of $3800 \mu \mathrm{g} / \mathrm{ml}$ and one of the isolate has shown to degrade $1920 \mu \mathrm{g} / \mathrm{ml}$ MP after $48 \mathrm{hrs}$. Such a high MP degrading potential by an isolate has not been reported so far. The reports of Arshad et al., 2008 may help in optimization of environmental parameters for biodegradation of such pesticide in contaminated soil by Pseudomonas sp. Bioremediation is a promising alternative to physico-chemical methods of remediation, because it is cost effective, can selectively achieve complete destruction of organic pollutants (Alexander, 1999). Bioremediation with the isolated strain in in situ can serve as an essential tool for removal of OPs. An effective method that was exemplified by resistant bacteria because it could be developed as a biological tool for cleaning of natural environments ( Zhongli C, 2001).

In conclusion, the present study findings reveals that higher concentration of Methyl Parathion attributes to the growth of bacterial isolates and different concentrations has an effect on optimum $\mathrm{pH}$ and temperature of isolates. As most of the soil microbes are known to be pathogens, this finding will prove beneficial, once mpd genes are cloned and expressed in E.coli, for evaluating degradation mechanism . There are enormous future aspect of this study. Identification and expression study of mpd gene can serve as a molecular or biochemical marker in assessing toxicity in clinical poisoning cases. Also, in target based studies, mpd expressed enzyme can detoxify organophosphorous toxicity. Numerous application of such genes can be evaluated in in silico analysis by targeting all other OP pesticide. Utility of mpd gene can be further extended to environmental monitoring systems to detect and detoxify the contaminated site by single or congruent culture and or enzyme extracts directly.

\section{References}

Ahmed, S. and Ahmed, M. S. (2006). Effect of Insecticides on the total number of soil bacteria under laboratory and field conditions. Pak Entamol. 28(2):63-67.

Amna Salman, Atefeh Taherian Fard, Arshan Nasir, and Habib Bokhari.( 2010). Comparative analysis of organophosphate degrading enzymes from diverse species. Bioinformation. 5(2): 67-72.

Arshad, M., S. Hussain and M. Saleem. (2008). Optimization of environmental parameters for biodegradation of alpha and beta endosulfan in soil slurry by Pseudomonas aeruginosa. J Appl Microbiol, 104 (2): 364-370.,

Alexander M (1999) Biodegradation and bioremediation, 2nd edn. Academic Press, London

Ali, M., K.N. Ahmed, A. Hameed and S.Ahmed.(2011), Biodegradation of Methyl parathion by newly isolated Bacillus pumilus Ti, Minerva Med, 2 (3): 39-43.

Bindhya, R., Sunny, S. A. and Thanga V. S. G. (2009). Invitro study on the 
influence of Methyl Parathion on soil bacterial activity. Journal of Environmental Biology. 30(3): 417419.

Charoensri, K., Esuchart, U., Nouwarath, S. and Pairote, P.(2001). Degradation of Methyl Parathion in an aqueous medium by soil bacteria. Science Asia. 27:261-271.

Chaudhry, G.R., A.N. Ali and W.B. Wheeler.(1988), Isolation of a methyl parathion degrading Pseudomonas sp. That possesses DNA homologous to the opd gene from a Flavobacterium sp. Appl Environ Microbiol, 54 (2): 288-293.

Cho T. H., Wild J. R., Donnelly K. C. 2000. Utility of organophosphorus hydrolase for the remediation of mutagenicity of methyl parathion. Environ. Toxicol. Chem. 19:2022-2028.

Cui, Z. L., Li, S. P., Fu, G. P.(2001) Isolation of Methyl Parathion degrading strain M6 and cloning of the Methyl Parathion hydrolase gene. Applied and Environmental Microbiology. 67:4922-4925.

Gaines, T.B., Acute toxicity of pesticides. Toxicol Appl Pharmacol, (1969)

Gevao, B., Semple, K.T., Jones, K.C., 2000. Bound pesticide residues in soils: a review. Environ. Pollut. 108, 14: 515535 ,

Gupta PK (2004). Pesticide Exposure-Indian Scene. Toxicol., 198: 83-90.

Hashmi, I., Kim, J. and Khan, M.A.(2002). Growth response of population of pseudomonas exposed to Malathion. 5(6):699-703.

Kanekar, P.P., Bhadbhade, B., Deshpande, N.M. and Sarnaik, S.S.,( 2004). Biodegradation of organophosphorus pesticides. Proceedings of Indian National Science Academy, 70: 57-70.

Keprasertsup, C., E.S. Upatham, N.
Sukhapanth and P. Prempree.(2001), Degradation of Methyl Parathion in an Aqueous Medium by Soil Bacteria. J Sci Asia, 27: 261-270.

Ortiz-Hernández ML, Monterrosas-Brisson M, Yañez-Ocampo G,Sánchez-Salinas E.2001. Biodegradation of methylparathion by bacteria isolated of agricultural soil. Rev.Int. Contam. Ambient, 17:147-155.

Ou, L.T and A. Sharma.(1989), Degradation of methyl parathion by mixed bacterial culture and a Bacillus sp. isolated from different soils. J Agr Food Chem, 37: 1514-8.

Ou LT et al (1983) Methyl parathion degradation in soil: influence of soilwater tension. Soil Biol Biochem 15, 211-5.

Ou L T (1985) Methyl parathion degradation and metabolism in soil: influence of high soil-water contents. Soil Biol Biochem 17, 241-3.

Pieper DH, Reineke W (2000). Engineering bacteria for bioremediation. Curr. Opin. Biotechnol., 11: 262-270.

Ritmann, B. E., Jackson, D. E. and Storck, S. L.(1988). Potential for treatment hazardous organic chemicals with biological process. Biotreatment systems.3. D. L. wise, Ed. CRC press, Boca Raton, FL. Pp 15-64.

Schnoor, L.J., (1992). Fate of pesticides and chemicals in the environment. The University of Lowa, Lowa city, Lowa. Wiley Interscience publication. John wiley and sons Inc. New York.

Sethunathan, N and T. Yoshida. (1973), A flavobacterium sp. that degrades diazinon and parathion. Can J Microbiol, 19 (7): 873-875.

Sharmila, M., Ramanand, K. and Sethunathan, N. (1989). Effect of yeast extract on the degradation of organophosphorus insecticides by soil enrichment and bacterial cultures. Can 
J. Microbiol. 35: 1105-1110.

Spadotto, C.A., Hornsby, A.G., (2003). Soil sorption of acidic pesticides: modeling $\mathrm{pH}$ effects. J. Environ. Quality.

Theriot CM, Grunden AM.(2011). Hydrolysis of organophosphorus compounds by microbial enzymes. Appl Microbiol Biotechnol. Jan;89(1):35-43.
Zhongli, C., Shunpeng, L and Guoping, F.(2001). Isolation of methyl parathiondegrading strain M6 and cloning of the methyl parathion hydrolase gene. Appl. Environ. Microbiol. 59: 4922-4925.

\section{How to cite this article:}

Sharmila Begum, S. and Arundhati, A. 2016. A study of Bioremediation of Methyl Parathion in vitro using Potential Pseudomonas sp. isolated from Agricultural Soil, Visakhapatnam, India Int.J.Curr.Microbiol.App.Sci.5(2): 464-474. doi: http://dx.doi.org/10.20546/ijcmas.2016.502.052 